\title{
INTERPRETATION AND CRITICISM OF BUDDHISM BY A.C. BHAKTIVEDANTA SWAMI PRABHUPĀDA
}

\author{
Janmani Talukdar
}

\begin{abstract}
Śrīla Prabhupāda has expressed his views/comments on different aspects of Buddhism purely based on the teachings of his predecessor ācāryas including his guru Bhaktisiddhānta Sarasvatī Thākur. On one hand, he categorically criticizes Lord Buddha's philosophy concerning many points/ teachings and on the other shows him due respect and reverence to Lord Buddha being an incarnation of the Supreme Personality of Godhead Lord Krrșna. While criticizing most of the teachings of Buddha Prabhupāda strictly adheres to the principles of bhaktimārga as the center point of comparison and illustrations. Though Prabhupāda has thrown light on the topic to some extent, still there is ample scope for further discussion on various points related to the same topic. This article is a study on the interpretation of Buddhist Principles by Srīla Prabhupāda in his commentary on the Bhagavadgit $\bar{a}$.
\end{abstract}

Śrīla Prabhupāda, whose real name was Abhay Caran De, was born in Kolkata in the year 1896. He met his spiritual master, Śrīla Bhaktisiddhānta Sarasvatī Thākur, in Calcutta in 1922. Bhaktisiddhānta Sarasvatī, a prominent religious scholar and the founder of sixty - four Gaudiya Mațhas, liked this educated young man and in 1933 he formally initiated him as his disciple. He requested Śñla Prabhupāda to preach Vedic knowledge in English. In the years that followed, Srīla Prabhupāda wrote a commentary on the Bhagavadgit $\bar{a}$. In 1947, He got the title 'Bhaktivedanta' from 
the Gaudiya Vaișnava society for his philosophical knowledge and devotional service. He established International Society for Krishna Consciousness (ISKCON) in July 1966 and guided it to grow to a worldwide confederation of more than one hundred āśramas, schools, temples, institutes and farm communities. Srīla Prabhupāda breathed his last on November 14, 1977.

Prabhupāda's most significant contribution is his books. He was a prolific writer and wrote more than hundred books. His masterpiece is Śrimad Bhāgavatam in 18 volumes. He has written so many books specially on devotion. He gives his interpretation on Ísopanișad also. Prabhupāda mainly discussed in his works Lord Krrṣna as the Supreme Personality of Godhead, means who the original form of the Absolute Truth. He explains that absolute position of Krrṣna is difficult to understand for any person who is not a devotee of Krșna in the paramparā system and only through bhakti yoga one can be freed from the cycle of births and deaths and finally can attain liberation.

His books are highly respected by scholars for their authority, depth and clarity. They are used as textbooks in many colleges. His writings have been translated into over fifty languages Śīla Prabhupāda's interpretation of the Gìtāis called Bhagavad-gìta As It Is. It is a complete and consistent explanation of the Git $\bar{a}$, in which Lord Krșnna's purpose to bring the readers to the way of devotion or bhaktiis perfectly served. Among the scholars of modern times, the name of A.C. Bhaktivedanta Swami, more popularly known as Śrīla Prabhupāda is noteworthy for his unique and pure presentation of the Gìtā.

Śrīla Prabhupāda has mentioned in his different books, lectures and conversations about Buddhism propagated by Gautama Buddha. In the interpretation of his Gìtā, Prabhupāda says that Lord Buddha was the incarnation of Lord Krșna, the Supreme Personality of Godhead. ${ }^{1} \mathrm{He}$ also mentions the name of the Bhägavata where it is said : Then in the beginning of Kali age, the 
son of Anjana, Buddha by name will take birth in Kikata for deluding the enemies of gods. ${ }^{2}$ Each and every incarnation of the Lord has a particular mission which is described in the revealed scriptures and on the basis of the scriptures only Buddha is to be regarded as an incarnation. It is said that when materialism was rampant and materialists were abusing the authority of the Vedas, at that time Buddhadeva appeared. ${ }^{3}$ There are certain rules and regulations regarding animal sacrifice for particular purpose in the Vedas. But some people took to animal sacrifice without reference to the Vedic principles. To stop this and to establish Vedic principles of non-violence Buddhadeva appeared. ${ }^{4}$ According to Prabhupāda, "in each and every incarnation He (God) speaks as much about religion as can be understood by the particular people under their particular circumstances. But the mission is the same to lead people to God consciousness and obedience to the principles of religion." ${ }^{5}$

Alluding to the life of Buddha, Prabhupāda says that Lord Buddha appeared in India roughly 2,600 years ago in a Hindu family as a son of high-grade kșatriya king and he left his princely life as a young man and renounced himself fully to a life of austerity, engaging in meditation for self-realization; Lord Buddha preached that he did not believe in the tenets of the Vedas and stressed the adverse psychological effects incurred by animal killing; People of Kali age followed his principles and they were trained in moral discipline and non-violence. ${ }^{6}$ According to Prabhupāda, "He deluded the atheists because such atheists who followed His principles did not believe in God, but they kept their absolute faith in Lord Buddha, who Himself was the incarnation of God. The faithless people were made to believe in God in the form of Lord Buddhadeva. That was the mercy of Lord Buddha, He made the faithless faithful to Him." ${ }^{\prime 7}$ Prabhupāda says that the animal killers are dangerous elements on the path of going back to Godhead. ${ }^{8}$ Lord Buddha tried to make such bewildered persons of 
atheistic propensity believer in God. Therefore, he first wanted to check the habit of animal killing.

The philosophy of Lord Buddha is technically called atheistic (nāstika) because there is no acceptance of the Supreme Lord and the authority of the Vedas. But Prabhupāda here says that that is an act of camouflage by him because Buddha is the incarnation of Godhead, as such, he is the original propounder of Vedic knowledge. Therefore though he cannot reject Vedas and Vedic philosophy, yet he rejected it outwardly because the demons who are always envious of the devotees to Godhead, try to support cow - killing or animal killing with the help of some statements of the Vedas. Even some modern sannyasis and scholars support this view. So Lord Buddha had to reject the authority of the Vedas altogether and this is simply technical, and had it not been so He would not have been so accepted as the incarnation of Godhead. ${ }^{9}$ Lord Buddha preached the preliminary principles of the Vedas to establish the authority of the Vedas in a manner suitable for the time - being. ${ }^{10}$

Lord Buddha is a lìla-avatāra, a scheduled incarnation who appears in each kalpa (i.e., a day of God Brahmā ). The purpose of the Buddha avatarais to preach commonsense religious principles. ${ }^{11}$ More specifically Prabhupāda states that Lord Buddha is a śaktyāveśaavatāra or empowered incarnation which is defined as the incarnation of Viṣnu's power invested in a living entity. ${ }^{12}$ Śaktyāveśaavatāras are also those souls whom God has invested with transcendental power of attorney for a particular purpose. ${ }^{13}$ Prabhupāda states, "when a jīva tattva becomes specifically empowered by the Lord, he is called śaktyāveśaavatāra. But they were not in conditioned state when they appeared; they came to teach here."14

It is true that Lord Buddha decried the Vedic principles and as such he is considered as atheist. But Prabhupāda makes it clear that though Vaisnavas are critical of many points of Lord Buddha's 
philosophy, yet they offer their respectful prayers to Lord Buddha. This is because they know how the God acts differently for His different purposes while others do not know that. ${ }^{15}$ Prabhupāda follows the declaration of the scriptures and the words of ŚrīCaitanya and other Vaiṣnavaācāryas, to show how the Vaiṣnavas or the Vedantists, theists and promoters of a different philosophy can accept Lord Buddha as a genuine representative of the Supreme Lord.

Śñla Prabhupāda says in the purport of the Caitanya Caritāmŗta that the scriptures of the Buddhist cult are chiefly based on argument and logic. He also mentioned that there are nine main principles of Buddhist path ${ }^{16}$. These nine principles are :

1. The creation is eternal; therefore there is no need to accept a creator.

2. This cosmic manifestation is false.

3. "I am" is the Truth.

4. There is repetition of birth and death.

5. Lord Buddha is the only source of understanding the path.

6. The principle of Nirvāna, is the Ultimate goal.

7. The philosophy of Buddha is the only philosophical path.

8. The Vedas are compiled by human beings and

9. Pious activities, showing mercy to others and so on are advised.

Although Prabhupāda has showed reverence to the Buddha as an incarnation of the Godhead, yet he has criticized his views very often. In his criticism of Buddhism Prabhupāda followed Śr̄̄ Caitanya as recorded in the Caitanya Caritāmŗta.

First principle of Buddhism is that the creation is always existent. But in that case, there can be no annihilation. On the other 
hand, according to Buddhism, annihilation or dissolution is the highest truth. Moreover, this argument is not acceptable because all material things have a beginning and end. ${ }^{17}$ The whole cosmic manifestation is a gigantic body and at a certain time it is certainly created and so the creator must have existed before the creation. This creator is Param Brahman or the Supreme Being, not a created being. The argument of the Buddhists that the world is false is not valid because the world is temporary, not false. ${ }^{18}$

Again, Prabhupāda mentions that according to the Buddhists, "I am" is the Ultimate Truth. This concludes the individuality of I and You. He argues that if there is individuality there can be no argument and Buddhist philosophy depends on argument. So, the duality of individual soul and the Supreme soul, must be admitted as is confirmed in the Gitta,

natvevāhamiātunāsaminatvaimnemejanādhipāh/

nacaivanabhavișyāmahsarvevayamatahparam//19

There were never a time when the Lord did not exist, nor the souls, nor all the kings, nor in the future shall any of them cease to be exist. Hence, the duality of Supreme soul and individual soul continues to exist from time immemorial and will continue in future also.

Again, Buddhism accepts the philosophy of transmigration. That means there is repetition of birth and death. But they do not properly explain this chain of birth and deaths. What will be the next birth of an individual is not clearly explained by them. It is not guaranteed that after every death there will be a human birth. ${ }^{20}$

The fifth principle also cannot be accepted which says that the Lord Buddha is the only source of understanding the truth. Lord Buddha rejected the principles of Vedic knowledge and one must accept a principle of standard knowledge because no one can attain Absolute Truth simply by intellectual speculation. ${ }^{21}$ 
Again, Nirvānais the ultimate goal of Buddhism. Nirvāna means annihilation. But Prabhupāda argues, "annihilation applies to the body but the spirit soul transmigrates from one body to another. If next birth is a fact, the next bodily form is also a fact. And we must accept that the body will be annihilated and that will accept another body. If all material bodies are doomed to annihilation, we must obtain a non-material body or a spiritual body. Highest perfection is that to give up one's material body and not accept another but to return back to Godhead."22

The argument that the Buddhist philosophy is the only way is also not acceptable because there are so many defects in that philosophy. In the view of Prabhupāda, Vedānta philosophy is the perfect one which has no defect. According to the Buddhists Vedas are compiled by ordinary human beings but that is not correct. Because after the creation the Supreme Lord imparted Vedic knowledge within the heart of Brahmā, otherwise they would not be authoritative. ${ }^{23}$

Mercy is one of the qualities of Buddhists which is also defective. Mercy should be for him who is suffering more than ourselves superior person cannot be object of mercy. Prabhupāda says that real mercy is to preach kṛșna Consciousness in order to revive the lost consciousness of human beings. ${ }^{24}$

It is generally advised that for any kind of material and spiritual progress one has to follow the past ācāryas or revealed scriptures. In this connection, one objection may be raised that Lord Buddha's philosophy was not in accord with the Vedic conclusions and therefore rejected. The Buddhists, who do not care for revealed scriptures, show devotional service to Him. In the Purport of Caitanya Caritāmŗta, Prabhupāda refers to Śamkarācārya who opposed the atheistic philosophy of Buddha. ${ }^{25}$ According to Prabhupāda, 'Lord Buddha's intention was to stop atheists from committing the sin of killing animals. Atheists cannot understand God; therefore Lord Buddha appeared and He spread the 
philosophy of non-violence to keep the atheists from killing animals. Unless one is free from the sin of animal killing, one cannot understand religion or God. Similarly, Śamkarācārya wanted to establish the predominance of one's spiritual identity, therefore he wanted to convert the atheists through an imaginary interpretation of the Vedic literatures. These are the secrets of ācarryas. Sometimes they conceal the real purport of the Vedas and explain the Vedas in a different way. Sometimes they enunciate a different theory just to bring the atheists under their control. ${ }^{26}$ Buddha's rejection of the Vedas should also be understood in this line. Prabhupāda says in his commentary in the similar line with Rovpa Goswāmī that the followers of Buddha cannot be accepted as devotees because though He is accepted as an incarnation of Kṛșna, the followers of such incarnations are not very advanced in their knowledge of the Vedas. ${ }^{27}$

Lord Buddha never speaks of a Supreme person or of the soul but began His philosophy from the premise that consciousness is the product of a combination of matter. Prabhupāda says, "this is the opinion of the modern scientists or the Buddha philosophy, that soul, there is nothing like soul separately, but by combination of matter, at a certain stage, the living symptoms are manifest. And as it is combination of several chemicals, so it is also finished as soon as the body finished. There is no, nothing as soul. That is their opinion. ${ }^{28}$ In his unique way Prabhupāda describes the concept of nirvanna advocated by Buddha. He says that Lord Buddha did not speak about the spiritual world but Buddha's philosophy said to dismantle the material existence which is nirvanna. ${ }^{29}$ The body is the combination of matter, so dismantle this combination. This is like dismantling a big building in order to be relieved from tax. In this word, "You have got a very big building so you have to pay tax, to save tax, break the building. No more taxes. No more pains and pleasures. No more anxiety that is Buddha philosophy." 30 The Vaiṣnavasregard Lord Buddha's this philosophy as limited but not entirely untrue .Prabhupāda says that Lord Buddha's teachings of 
Nirvanaare based on that the material body is composed of five gross elements - earth, water, air, fire and ether and three subtle elements - mind, intelligence and ego; when one attains liberation, he is freed from these material coverings. So he instructed his followers to give up these material coverings by means of meditation and yoga. One who follows this strictly will ultimately become free from the material coverings and attain nirvanna. ${ }^{31}$

According to Lord Buddha's version, the final destination is one of complete negation, a void or zero (śvinya) state because he ignored the presence of the spiritual soul or God where there is no question of anything positive beyond the material realm - neither bliss, nor cognizance, nor even real existence. So, Prabhupāda writes, "HisNirvānaphilosophy means stopping all material activities. Lord Buddha did not recognize the presence of transcendental forms and spiritual activities beyond the material world. He simply described voidism beyond this material existence." $^{\prime 32}$

Prabhupādathen shows how Buddha's conception of Nirvāna agrees and disagrees with Vaiṣnava teachings by comparison. To make everything void or zero is the Buddhist philosophy which is not possible because all living beings have desires so desirelessness is not possible. ${ }^{33}$ So he says, "if you have got a pinch of desire to enjoy this material world, then you will have to remain here as, either as Brahmā or as a small ant, according to your karma. But you when completely become free from material attachment, then the spiritual world is.... So when the Buddha philosophy says śvinyavāda, nirvāna, it means the same thing vita - rāga, you have to become detached. You have to make this material enjoyment zero. The bhakti also says, bhakti formula, anyābhilāṣitāśñnyam : $:^{34}$ you have to make your heart cleansed of all material desires. Then spiritual life will begin." 35

Buddhists religious philosophy may be seen as incomplete or incorrect from the Vedic perspective but Prabhupāda maintains 
that such teaching was necessary under the circumstances of Lord Buddha's appearance to give his followers a first step towards further spiritual advancement. Sohe says that Buddha's Nirvānaand Śñnyavāda philosophies were meant for the extreme materialists who could not begin to understand spiritual life. ${ }^{36}$

Again Prabhupāda makes an interesting point of Buddhism. Buddhists say that there is no God, there is no soul, but there are thousands of temples of Lord Buddha specially in the countries like Japan, China, Burma and they worship with lamp, candle respectfully in the same way as we worshiping the Lord and there are brahmacāris and sannyāsis also. ${ }^{37}$

From the foregoing discussions it is evident that Srīla Prabhupāda has explained the concept of Buddhism in his different works in a unique way. In this connection he has followed his illustrious predecessors like Śrī Caitanya, Rōpa Gosvāmi and many others. Although he has accepted Gautama Buddha as an incarnation of Lord Kṛșna, still he has not supported most of the teachings of Buddha as he has strictly adhered to the bhaktimārga and personal features of the Supreme Personality of Godhead Lord Krș̣na based on knowledge percolated down through guru

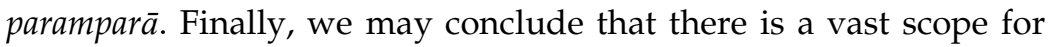
discussion on the vital subject as aforementioned with spectrum of topics.

\section{Notes and References :}

1 Śrīla Prabhupāda, Bhagavad-GïtāAs It Is, p.199

2 tatahkalausampravrttesammohōyasuradvișām/ Buddhonāmāñjanāsutahkīkațeșubhavișyati// Bhāgavata, 1.3.24

3 Śrīla Prabhupāda, Bhagavad-Gītā As It Is, p.199

4 Ibid. , p.200

5 Ibid.

${ }^{6}$ Śrīla Prabhupada, Śrimad Bhāgavatam, 1.3.24, pp.169,171 
7 Ibid., p.169

8 Ibid. , p.170

9 Ibid.

${ }^{10}$ Ibid. , p.171

11 Śrīla Prabhupāda, Śrīmad Bhāgavatam, 2.7.37 , p. 421

12 Ibid. , 4.19.37, p.846

${ }^{13}$ Ibid. , 3.5.21, p.208

${ }^{14}$ Letter to Aniruddha, Los Angles, 14 November, 1968

${ }^{15}$ Lord Varāha's appearance Day lecture, Los Angles, February 18, 1970

${ }^{16}$ tarka - pradhāna Buddha - śāstranava mate /

tarkeikhandilāprabhu, nāpāresthāpite// Caitanya Caritāmṛta, Madhya, 9.49

17 Śrīla Prabhupāda, Caitanya Caritāmrta (Bengali) Madhya, 9.49, p.621

18 Ibid. , p.622

${ }^{19}$ Gìtā, 2.12

${ }^{20}$ Śrīla Prabhupāda, Caitanya Caritāmṛta (Bengali) Madhya, 9.49, p.622

21 Ibid.

${ }^{22}$ Ibid., p.623

23 Ibid.

${ }^{24}$ Ibid., p.624

${ }^{25}$ Śrīla Prabhupāda, Caitanya Caritāmrta (Bengali)Madhya, 25.42, p.581

${ }^{26}$ Ibid.

27 Śrīla Prabhupāda, Nectar of Devotion, 7, p. 61

${ }^{28}$ Lecture on Gītā, 2.26, Hyderabad, 30 November, 1972

${ }^{29}$ Room Conversation with two Buddhist Monks, July 12, 1973

${ }^{30}$ Room conversation, February 15, 1972, Madras

31 Śrīla Prabhupāda, Śrīmad Bhāgavatam, 4.23.15, p.263

32 Śrīla Prabhupāda, Caitanya Caritāmrta, (Bengali) , Madhya, 6.168 , p.377

${ }^{33}$ Lecture on Bhāgavata, 6.1.51 , Detroit, August 4, 1975

${ }^{34}$ Bhaktirasāmrtasindhu, 1.1 .11 
${ }^{35}$ Lecture on Gïtā, 4.11, Bombay, March 31, 1974

${ }^{36}$ www.vanipedia.org, Buddha : A Vaisnava Perspective

${ }^{37}$ Lecture on Bhāgavata, 1.2.6 , August 3, 1968, Montreal.

\section{Bibliography :}

Prabhupāda, A.C. Bhaktivedanta Swami. Bhagavad-gìtā As It Is. The Bhaktivedanta Book Trust, Mumbai, 1986 (2nd Edition)

_ Caitanya Caritāmrta. The Bhaktivedanta Book Trust, Calcutta, 1995

. The Nectar of Devotion. The Bhaktivedanta Book Trust, Bombay, 1985

Śrimadbhāgavatam. TheBhaktivedanta Book Trust, Bombay, 1987

Radhakrishnan, S. Indian Philosophy. Vol- I. Second Edition, OXFORD University Press, New Delhi, 2008

Sinha, K.P. A Critique of A.C. Bhaktivedanta. Punthi - Pustak, Calcutta, 1997 